\title{
Correction to: Correlation
} between intraoperative and postoperative vaulting of the EVO implantable Collamer lens: a retrospective study of real-time observations of vaulting using the RESCAN 700 system

Nian Guan ${ }^{1}$, Xiao-Nong Zhang ${ }^{2}$ and Wan-Jun Zhang ${ }^{2^{*}}$

Correction to: BMC Ophthalmol 22, 2 (2021)

https://doi.org/10.1186/s12886-021-02237-2

Following the publication of the original article [1], we were notified that Figures 1 and 2 were incorrect. 
Originally published figures:

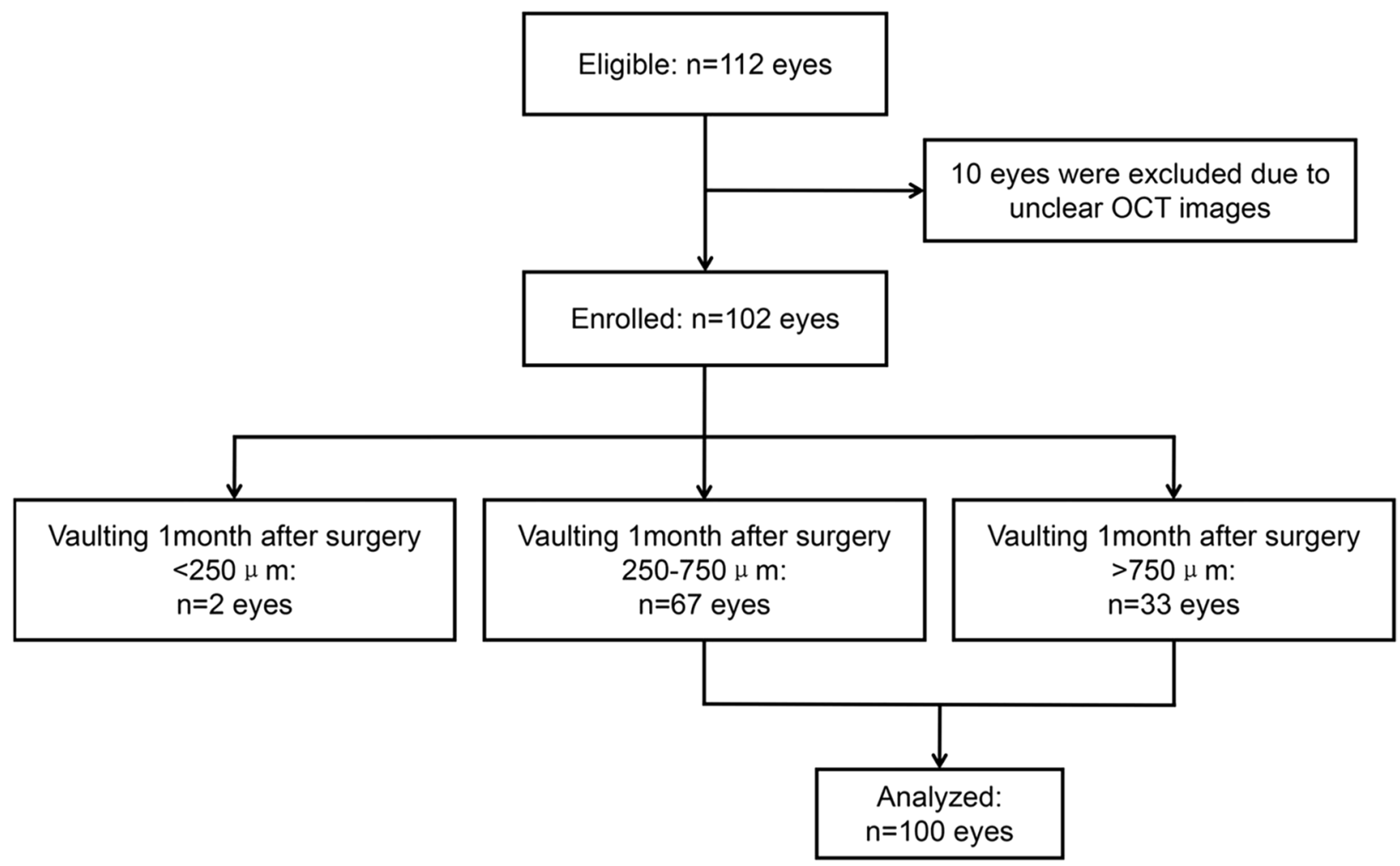

Figure 1. Linear correlation between intraoperative vaulting and the vaulting at 1 month after surgery. X-axis: intraoperative vaulting. Y-axis: vaulting at 1 month after surgery.
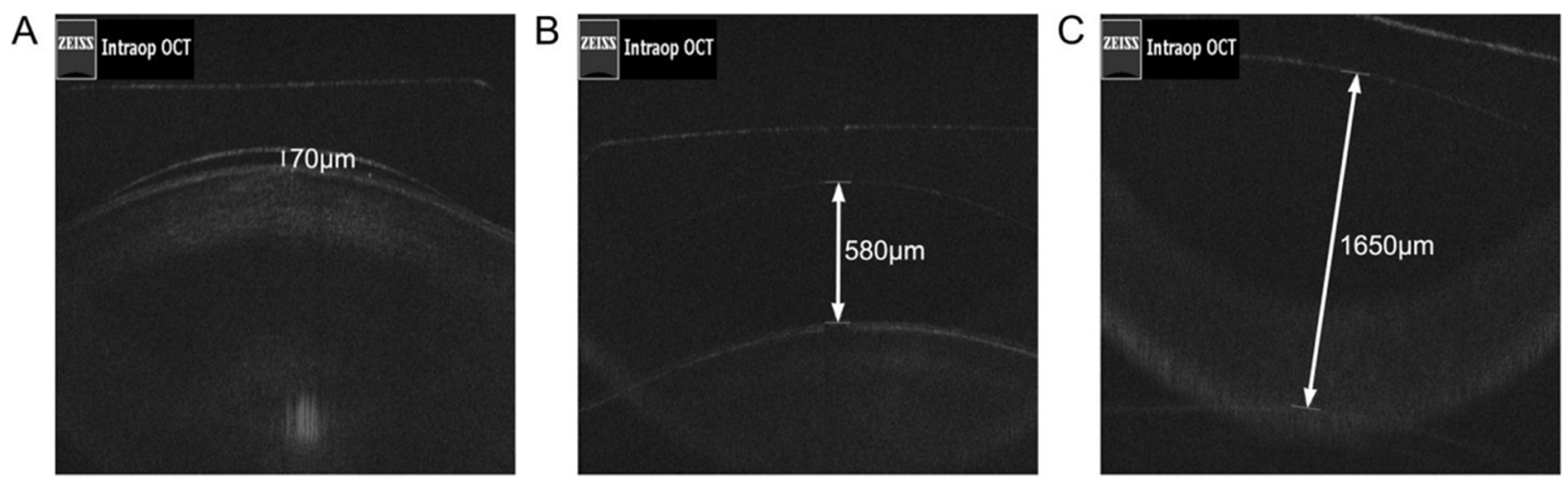

Fig. 2 Typical figures for measuring vaulting (intraoperative). (A) Low intraoperative vaulting; (B) Normal intraoperative vaulting; (C) High intraoperative vaulting. 


\section{Corrected figures:}
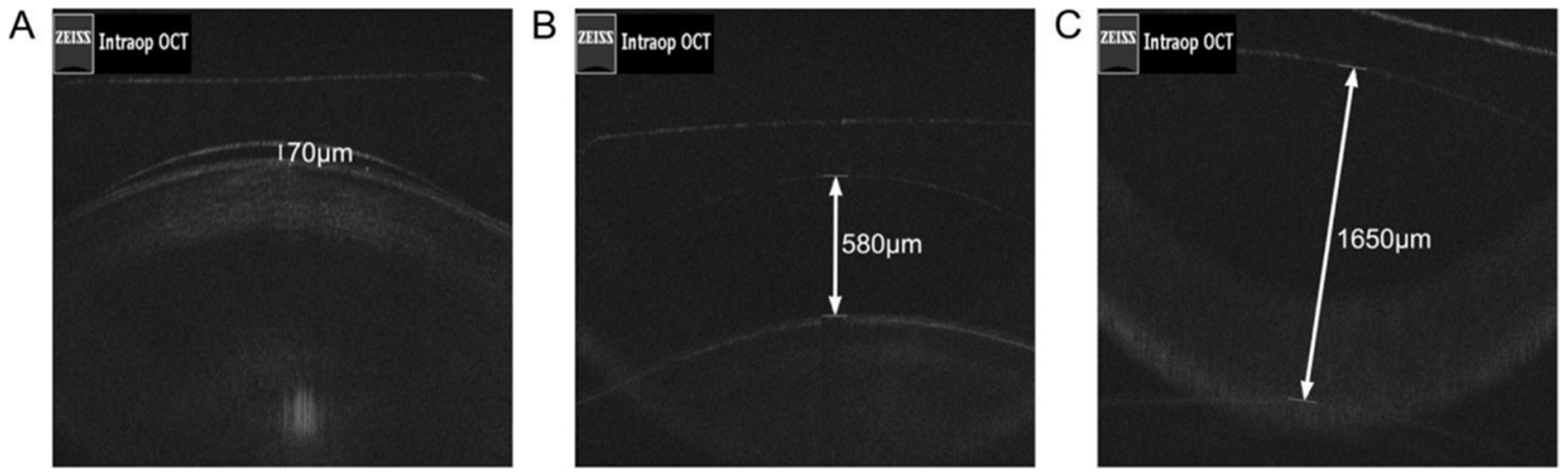

Fig. 1 Typical figures for measuring vaulting (intraoperative). (A) Low intraoperative vaulting; (B) Normal intraoperative vaulting; (C) High intraoperative vaulting.

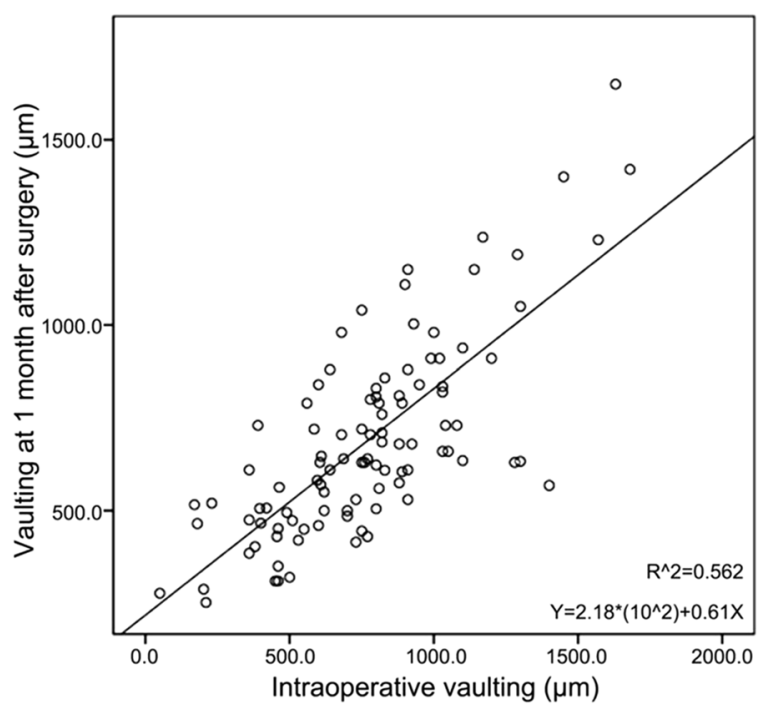

Figure 2. Linear correlation between intraoperative vaulting and the vaulting at 1 month after surgery. X-axis: intraoperative vaulting. Y-axis: vaulting at 1 month after surgery.

The original article has been corrected.

\section{Author details}

'Department of Refractive, Wuhan Bright Eye Hospital, Wuhan 430000, Hubei, China. ${ }^{2}$ Department of Refractive, Hefei Bright Eye Hospital, Hefei 230000, Anhui, China.

Published online: 23 February 2022

\section{Reference}

1. Guan N, et al. Correlation between intraoperative and postoperative vaulting of the EVO implantable Collamer lens: a retrospective study of real-time observations of vaulting using the RESCAN 700 system. BMC Ophthalmol. 2021;22:2. https://doi.org/10.1186/s12886-021-02237-2.

Ready to submit your research? Choose BMC and benefit from:

- fast, convenient online submission

- thorough peer review by experienced researchers in your field

- rapid publication on acceptance

- support for research data, including large and complex data types

- gold Open Access which fosters wider collaboration and increased citations

- maximum visibility for your research: over $100 \mathrm{M}$ website views per year

At BMC, research is always in progress.

Learn more biomedcentral.com/submissions 